\title{
COVID-19 Fatality: Statistical Evidence to Engender the Need for Focal Shift from Air Pollutants to Multi-dimensional Intervention
}

Special Issue:

Special Issue on COVID-19 Aerosol Drivers, Impacts and Mitigation (IX)

\section{OPEN ACCESS}

Received: July 16, 2020

Revised: September 11, 2020

Accepted: September 17, 2020

* Corresponding Author:

boopathy@immt.res.in;

chemboopathy@gmail.com

\section{Publisher:}

Taiwan Association for Aerosol Research

ISSN: $1680-8584$ print

ISSN: 2071-1409 online

(c) Copyright: The Author(s) This is an open access article distributed under the terms of the Creative Commons Attribution License (CC BY 4.0), which permits unrestricted use, distribution, and reproduction in any medium, provided the original author and source are cited.

\author{
Satya S. Patra ${ }^{1}$, Subhasmita Panda ${ }^{1,2}$, Trupti Das ${ }^{1,2}$, Boopathy Ramasamy ${ }^{1 *}$ \\ ${ }^{1}$ Environment \& Sustainability Department, CSIR-Institute of Minerals \& Materials Technology \\ (CSIR-IMMT), Bhubaneswar, India \\ ${ }^{2}$ Academy of Scientific and Innovative Research (ACSIR), CSIR-Institute of Minerals \& Materials \\ Technology (CSIR-IMMT), Bhubaneswar, India
}

\section{ABSTRACT}

Since the outbreak of COVID-19 pandemic, several researchers worldwide have suggested chronic exposure to air pollutants viz. $\mathrm{PM}_{2.5}, \mathrm{NO}_{2}$, and $\mathrm{O}_{3}$ as one of the influencing factors for the increased rate of fatality. However, most of these studies lacked a comprehensive international outlook. A strong correlation on a regional scale might require further investigations to evaluate the transboundary validity. Therefore, the current study aims to explore the statistical soundness of association of COVID-19 fatality with $\mathrm{PM}_{2.5}, \mathrm{NO}_{2}$, and $\mathrm{O}_{3}$ concentration levels across 463 air quality monitoring stations located in 35 selected cities from USA, India and European Regions (France, Germany and Italy). An aggregated open-source air quality data source was used to download the $\mathrm{PM}_{2.5}, \mathrm{NO}_{2}$, and $\mathrm{O}_{3}$ concentration for $>900$ days in the selected cities. The median of this long-term exposure was tested against the COVID-19 fatality rates. A strength of association parameter, $\omega^{2}$, and the coefficient of determination, $R^{2}$, were used to evaluate the transboundary association. $\omega^{2}$ results indicated that only $24.6 \%, 0.03 \%$ and $15.4 \%$ of the variation in COVID-19 fatality rates could be explained using $\mathrm{PM}_{2.5}, \mathrm{NO}_{2}$, and $\mathrm{O}_{3}$ concentrations respectively for all the analyzed cities. Further, low values of $R^{2}$ between pollutant concentrations and COVID-19 fatality rates corroborated the results $\left(0.27\right.$ for $\mathrm{PM}_{2.5}, 0.00038$ for $\mathrm{NO}_{2}$ and 0.18 for $\left.\mathrm{O}_{3}\right)$. These observations strongly suggest a focal shift towards the inclusion of more explanatory variables and an extensive multi-disciplinary work is required in order to understand the cause of COVID-19 fatality.

Keywords: COVID-19, Air quality, Fatality rate

\section{INTRODUCTION}

Corona virus disease 2019 (COVID-19) caused by Severe Acute Respiratory Syndrome Corona Virus 2 (SARS-CoV-2) was first identified in Wuhan city of China in December 2019 (Chen et al., 2020) and later became a pandemic. Since its outbreak, the contagious infection spread across 216 countries, affecting more than 10 million people and claiming over 555,642 lives worldwide as on $11^{\text {th }}$ July 2020 (https://covid19.who.int/). The course of COVID-19 infection gradually starts with mild flu-like symptoms or no symptoms and further progress to infect the respiratory system of the infected individual. In certain severe cases, however, it might lead to death due to Acute Respiratory Distress Syndrome (ARDS) and pneumonia (Li and Ma, 2020). The widespread magnitude of this catastrophe has, therefore, made it critical for people to understand various aspects of COVID-19, its spread and prevention as well as its impact on health, economy, etc. Since, COVID-19 is primarily a respiratory syndrome, and several epidemiological studies suggests that chronic exposure to air pollutants viz. $\mathrm{PM}_{2.5}, \mathrm{NO}_{2}$ and $\mathrm{O}_{3}$ can increase the risk for cardio respiratory mortality and morbidity (Russell and Brunekreef, 2009; Pope, 2000; Sicard et al., 2019), recently, some studies tried to statistically explore whether pollutant exposure can 
influence the likelihood of COVID-19 fatality.

In this context, Frontera et al. (2020) reported a correlation of 0.53 between mean $\mathrm{PM}_{2.5}$ and COVID-19 deaths in worst COVID-19 affected regions in Italy. Similarly, Ogen, 2020 has also reported higher correlation between long-term exposure to $\mathrm{NO}_{2}$ and COVID-19 fatality in Italy and Spain. Along the same lines, Wu et al. (2020), Pansini and Fornacca (2020), and Yao et al. (2020) reported a strong association between COVID-19 fatality rate and PM concentrations for USA and China. Table 1 summarizes some of the previously published study relating the fatality rate of COVID-19 with chronic exposure to air pollutants. These studies primarily examined the significant association of the geo-environmental determinants with COVID-19 fatality cases on a regional scale or within a country. However, a strong correlation on a regional scale might require further investigations to evaluate its transboundary validity. Therefore, in this pursuit, the primary objective of this study is to assess the statistical soundness of association of chronic air pollutant exposure viz. $\mathrm{NO}_{2}, \mathrm{O}_{3}, \mathrm{PM}_{2.5}$ with COVID-19 fatality rate over a broader perspective. The statistical analysis was performed for 35 different cities located across five different countries (USA, India, France, Germany and Italy). The corresponding data collection and its processing are discussed in the methodology, and its results are discussed in the results and discussion section.

\section{METHODOLOGY}

\subsection{Data Collection and Processing}

The hourly surface $\mathrm{NO}_{2}, \mathrm{O}_{3}$, and $\mathrm{PM}_{2.5}$ concentration levels were obtained for 463 air quality

Table 1. Summary of previous published literature on association of air pollutants with COVID-19 fatality.

\begin{tabular}{|c|c|c|c|c|}
\hline Country & Pollutant & Pollutant Source & Inference & Reference \\
\hline Italy & - & - & $\begin{array}{l}\text { A high level of pollutant in Northern } \\
\text { Italy is considered as an additional co- } \\
\text { factor of the increased fatality rate }\end{array}$ & $\begin{array}{l}\text { Conticini et } \\
\text { al., } 2020\end{array}$ \\
\hline Italy & $\mathrm{PM}_{2.5} \& \mathrm{NO}_{2}$ & $\begin{array}{l}\text { Air-matter } \\
\text { https://air- } \\
\text { matters.com/ }\end{array}$ & $\begin{array}{l}\text { Proposed a "double hit hypothesis": } \\
\text { prolong exposure of } \mathrm{PM}_{2.5} \text { and } \mathrm{NO}_{2} \\
\text { results in lung depletion thus causing a } \\
\text { severe form of SARS-CoV-2 }\end{array}$ & $\begin{array}{l}\text { Frontera et } \\
\text { al., } 2020\end{array}$ \\
\hline $\begin{array}{l}\text { France, Germany, } \\
\text { Italy, and Spain }\end{array}$ & $\mathrm{NO}_{2}$ & $\begin{array}{l}\text { Sentinel-5 Precursor } \\
\text { spaceborne satellite }\end{array}$ & $\begin{array}{l}\text { The two main hotspots of } \mathrm{NO}_{2} \text { over } \\
\text { Europe i.e., north Italy and central } \\
\text { Spain, showed the highest fatality rate } \\
\text { due to long term exposure to } \mathrm{NO}_{2} \text {. }\end{array}$ & Ogen, 2020 \\
\hline US & $\mathrm{PM}_{2.5}$ & $\begin{array}{l}\text { Atmospheric } \\
\text { Composition Analysis } \\
\text { Group } \\
\text { http://fizz.phys.dal.ca/ } \\
\sim \text { atmos/martin }\end{array}$ & $\begin{array}{l}\text { A slight increase in long term exposure } \\
\text { to PM } 2.5 \text { led to a significant increase in } \\
\text { the COVID-19 mortality rate }\end{array}$ & $\begin{array}{l}\text { Wu et al., } \\
2020\end{array}$ \\
\hline US & $\mathrm{PM}_{2.5}$ & $\begin{array}{l}\text { US Environmental } \\
\text { Protection Agency } \\
\text { (EPA) }\end{array}$ & $\begin{array}{l}\text { COVID-19 fatality and transmission } \\
\text { were significantly related to diesel } \\
\text { PM2.5as compared to general } \mathrm{PM}_{2.5}\end{array}$ & $\begin{array}{l}\text { Hendryx and } \\
\text { Luo, } 2020\end{array}$ \\
\hline US & $\mathrm{NO}_{2}, \mathrm{O}_{3}, \mathrm{PM}_{2.5}$ & $\begin{array}{l}\text { Ensemble machine } \\
\text { learning model }\end{array}$ & $\begin{array}{l}\text { Prolonged exposure to } \mathrm{NO}_{2} \text { enhanced } \\
\text { the COVID-19 fatality rate. Whereas, } \\
\text { no significant statistical association } \\
\text { was found between } \mathrm{PM}_{2.5} \text { and } \mathrm{O}_{3} \text { to } \\
\text { the death rate }\end{array}$ & $\begin{array}{l}\text { Liang et al., } \\
2020\end{array}$ \\
\hline $\begin{array}{l}\text { US, Italy and } \\
\text { China }\end{array}$ & $\begin{array}{l}\mathrm{NO}_{2}, \mathrm{PM}_{2.5}, \mathrm{CO} \\
\mathrm{O}_{3}, \mathrm{SO}_{2}, \mathrm{HCHO} \\
\text { UV aerosol index }\end{array}$ & $\begin{array}{l}\text { Ground monitoring } \\
\text { stations and Sentinel-5 } \\
\text { satellite }\end{array}$ & $\begin{array}{l}\text { COVID-19 cases are more prevalent in } \\
\text { extremely polluted areas of the US, } \\
\text { Italy, and China. A higher } \\
\text { concentration of pollutants viz. PM } 2.5 \text {, } \\
\text { CO, and } \mathrm{NO}_{2} \text { enhanced the COVID-19 } \\
\text { fatality rate }\end{array}$ & $\begin{array}{l}\text { Pasini and } \\
\text { Foranco, } 2020\end{array}$ \\
\hline
\end{tabular}


monitoring stations spanning across 35 selected cities in five countries (India, Germany, France, Italy and USA) from an open source data aggregator website, OpenAQ (https://openaq.org). The observations in OpenAQ are majorly from various government agencies of their respective countries. It has an archive of air quality data collected from more than 12,000 air qualitymonitoring stations situated in 93 countries across the globe. There are reports that researchers have previously used this platform to understand the global pollutant patterns (Manning et al., 2018).

Fig. 1 shows the number of monitoring stations analysed from each of the selected city. The selection of pollutant parameters $\left(\mathrm{PM}_{2.5}, \mathrm{NO}_{2}\right.$, and $\left.\mathrm{O}_{3}\right)$ was inspired from previous studies, which revealed that chronic exposure to these pollutants might lead to increase in respiratory stress (Pope, 2000; Sicard et al., 2019). Furthermore, the choice of cities and countries are based on availability of ground-based $\mathrm{PM}_{2.5}, \mathrm{NO}_{2}$ and $\mathrm{O}_{3}$ data, and the high COVID-19 infection rates. Since the effectiveness of pollutants on fatality depends upon the exposure time, we have considered median values of concentrations calculated from the collected data (2018-2020). Also, as the OpenAQ website does not provide explicit information on errors in measurement, prior to the calculation of median, data were filtered for the outliers. The outliers were detected in a moving window of 10 data points where anything above Eq. (1) and below Eq. (2) were removed from the dataset (Benkert et al., 2008).

Third Quartile + $1.5 \times$ Inter Quartile range

First Quartile - $1.5 \times$ Inter Quartile range

Record of number of COVID-19 confirmed and deceased cases were obtained from different credible government and local websites for each selected city until $1^{\text {st }}$ July 2020 . Globally, almost 74,630 COVID-19 death cases were accounted in this analysis. The city wise fatality rate was determined using the Eq. (3).

COVID-19 Fatality rate $=\frac{\text { Number of deceased COVID-19 cases in the city }}{\text { Number of confirmed COVID-19 cases in the city (in } 100 \mathrm{~s})}$

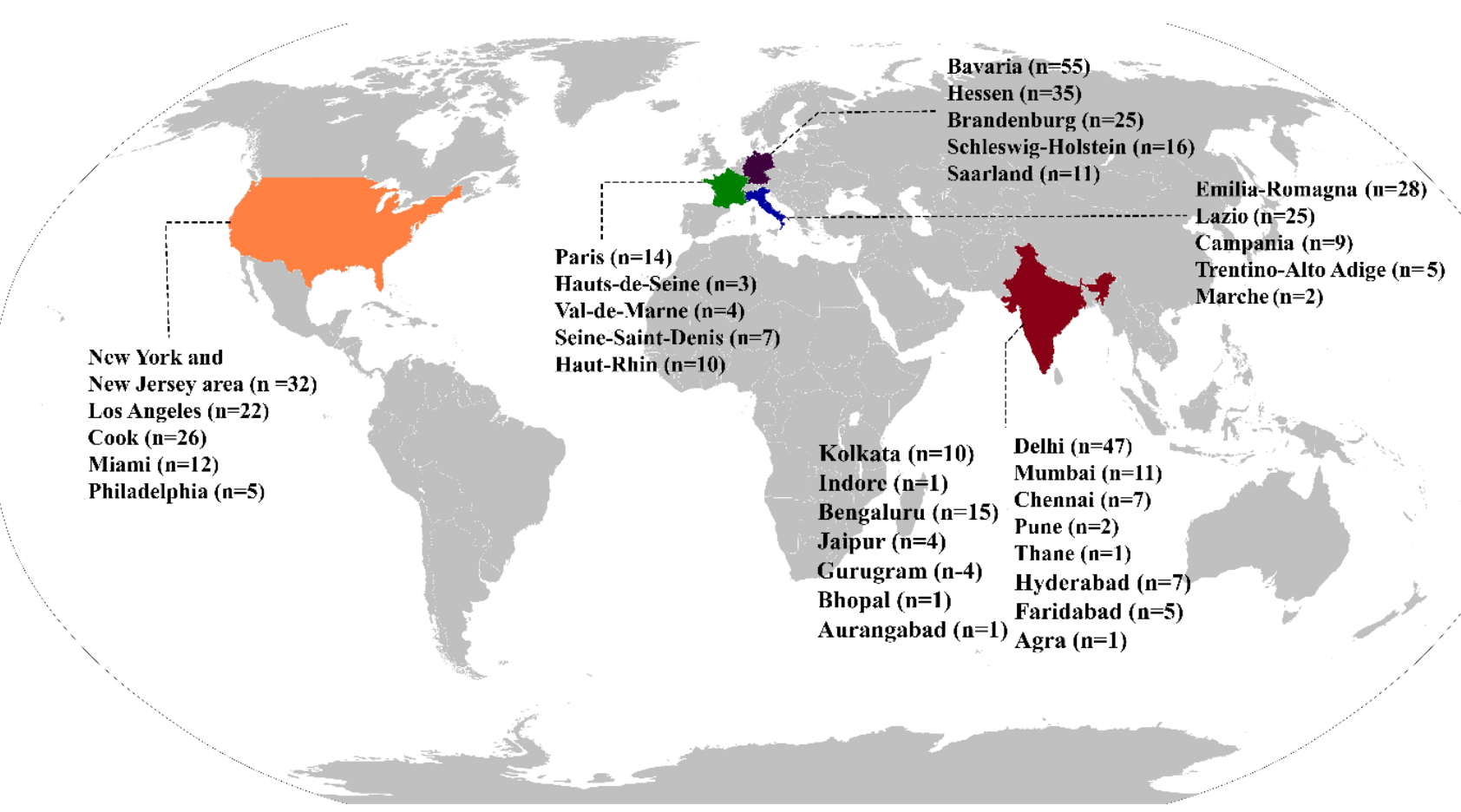

Fig. 1. Number of air quality monitoring stations analyzed from 35 cities in 5 different countries in the present investigation. 


\subsection{Statistical Analysis}

The goal of the current study is to explore the association of COVID-19 fatality rate relative to long-term exposure of $\mathrm{NO}_{2}, \mathrm{O}_{3}$, and $\mathrm{PM}_{2.5}$ concentrations for the selected cities. To quantify this association, a strength of association statistic, $\omega^{2}$, is used. Omega squared, $\omega^{2}$, is a descriptive statistic that determines the strength of association between an explanatory variable and a response variable (Stephanie, 2016). A detailed methodology to calculate $\omega^{2}$ is explained elsewhere (Salkind, 2010).

The values of $\omega^{2}$ lies between 0 and 1 , where 0 indicates no association, and 1 indicates that all the variation in the response variable can be explained using the explanatory variable. Here, the processed pollutant $\left(\mathrm{NO}_{2}, \mathrm{O}_{3}\right.$, and $\left.\mathrm{PM}_{2.5}\right)$ concentrations were considered as the explanatory variable, and the COVID-19 fatality rate formed the response variable. The present study basically aims to investigate what amount of variability of COVID-19 fatalities that could be explained by the pollutants $\left(\mathrm{NO}_{2}, \mathrm{O}_{3}\right.$, and $\left.\mathrm{PM}_{2.5}\right)$, but not to establish the sign of the correlation or the significance of correlation. Therefore, such a statistic, $\omega^{2}$, was selected. Commenting on sign of correlation and its significance would require epidemiological interventions rather than only statistical analysis (Bontempi et al., 2020). However, to bolster the $\omega^{2}$ results, a common association parameter, coefficient of determination, $R^{2}$, was also calculated for each pollutant and COVID-19 fatality rates.

\section{RESULTS AND DISCUSSION}

The median $\mathrm{PM}_{2.5}, \mathrm{NO}_{2}$ and $\mathrm{O}_{3}$ concentrations of all the 35 selected cities along with their COVID-19 fatality rates is listed and presented in the supplement section (Table S1). To understand the pattern of median $\mathrm{PM}_{2.5}, \mathrm{NO}_{2}$ and $\mathrm{O}_{3}$ concentrations with COVID-19 fatality rate, scatter plots between them were drawn for the 35 selected cities (Fig. 2). Fig. 2 depicts no clear association between concentrations of $\mathrm{PM}_{2.5}, \mathrm{NO}_{2}$ and $\mathrm{O}_{3}$, and the fatality rate of COVID-19. Cities in India experiencing higher $\mathrm{PM}_{2.5}$ concentrations are marked with low fatality rates, whereas the distribution of fatality rates in low PM polluted cities is arbitrary. Furthermore, the data points on $\mathrm{O}_{3}$ and $\mathrm{NO}_{2}$ plots indicate that their concentration is widely spread, following no apparent trend, with respect to COVID-19 fatalities.

To understand the amount of variability in COVID-19 fatality rates that can be explained using pollutant concentration, $\omega^{2}$ and $R^{2}$ values were calculated. The results of statistical analysis are summarized in Table 2 . In the analyzed cities, $\omega^{2}$ values indicate that $\mathrm{PM}_{2.5}, \mathrm{NO}_{2}$, and $\mathrm{O}_{3}$ could explain only $24.6 \%, 0.03 \%$ and $15.4 \%$ of variation in COVID-19 fatality rates, respectively. In addition, the observed $\mathrm{R}^{2}$ values were $0.27,0.00038$ and 0.18 for $\mathrm{PM}_{2.5}, \mathrm{NO}_{2}$, and $\mathrm{O}_{3}$, respectively. Such lower values of $\omega^{2}$ and $R^{2}$ shows that the pollutant concentration data is noisy relative to COVID-19 fatality rate, and not statistically sufficient to explain the variability in the data. This is also reflected in higher values of sum of squares of residuals. Therefore, the results indicate that when the association between the COVID-19 fatality rates and long-term pollutant concentrations were explored over different worst-affected COVID-19 countries as a whole, they could explain only a fraction of COVID-19 fatality variation. This suggests that COVID-19 fatality might be influenced by a number of other co-factors, like age, co-morbidities, cross-immunities etc. (Chakrabarti et al., 2020). Concentration of air pollutants might have a secondary effect on some of these variables. However, to completely understand the COVID-19 fatality function, cumulative impact of all the potentially influencing other variables should be considered. This engenders the need for a multidimensional and multi-disciplinary investigation to better comprehend the fatality levels of COVID-19 globally.

\section{CONCLUSIONS}

This cohort study evaluated the association of $\mathrm{PM}_{2.5}, \mathrm{NO}_{2}$ and $\mathrm{O}_{3}$ concentration with COVID-19 fatality rate across 35 different cities located in 5 different countries. For the same, ground level pollutant concentrations $\left(\mathrm{PM}_{2.5}, \mathrm{NO}_{2}\right.$ and $\left.\mathrm{O}_{3}\right)$ for $>900$ days were downloaded from OpenAQ website and processed for the present investigation. A strength of association statistic, $\omega^{2}$, and the coefficient of determination, $R^{2}$, were used to assess the relationship. Upon analysis, the $\omega^{2}$ 

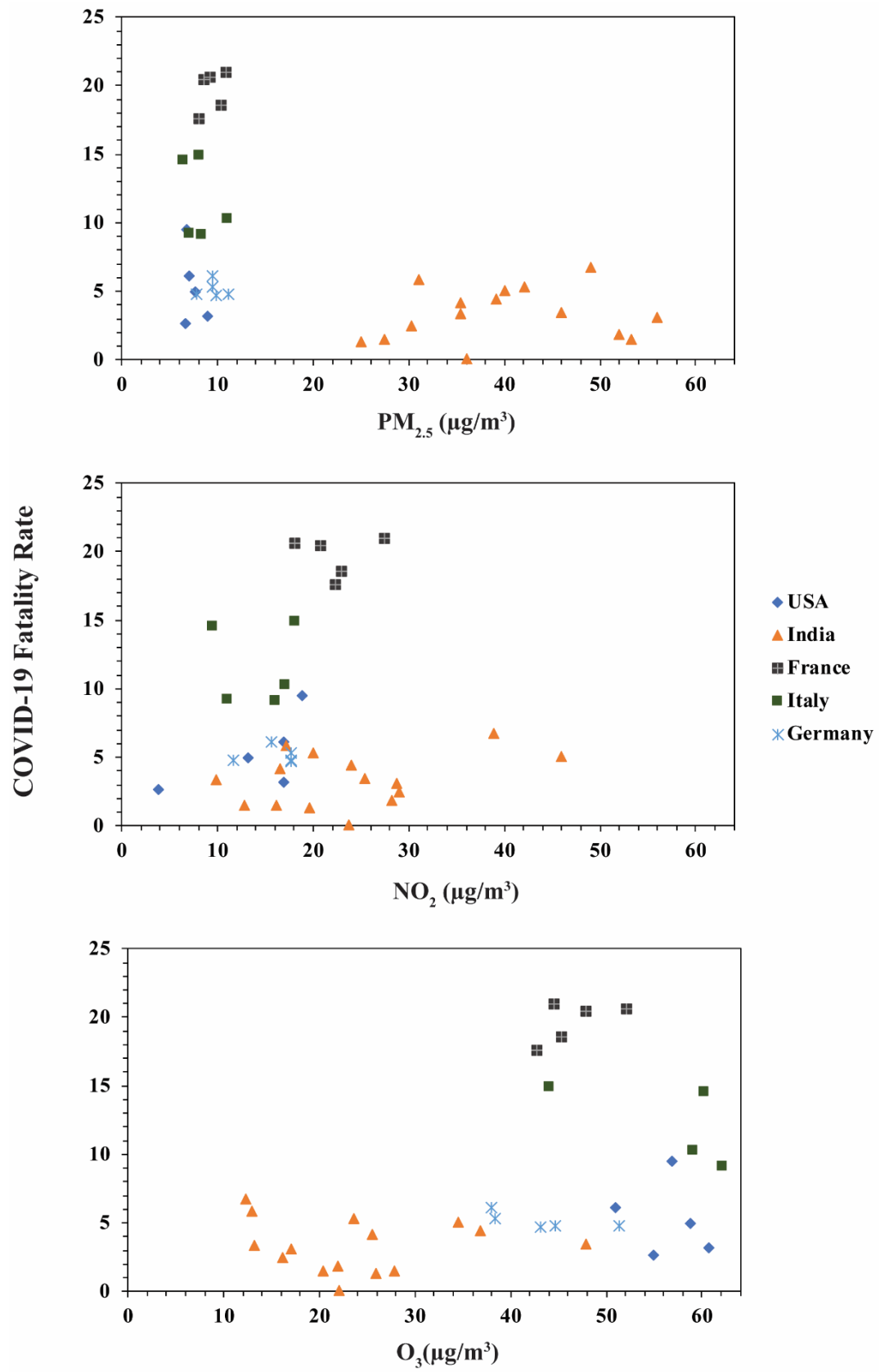

Fig. 2. Scatter plots of pollutant concentrations $\left(\mathrm{PM}_{2.5}, \mathrm{NO}_{2}, \mathrm{O}_{3}\right)$ with COVID-19 fatality rate for the identified cities ( 35 cities) in the present investigation.

Table 2. Statistical summary of association of pollutant concentrations with COVID-19 fatality rates over analysed cities.

\begin{tabular}{llll}
\hline Pollutant & Residual Sum of Squares & $R^{2}$ & $\omega^{2}$ \\
\hline $\mathrm{PM}_{2.5}$ & 912.64 & 0.27 & 0.246 \\
$\mathrm{NO}_{2}$ & 1257.19 & 0.00038 & 0.0003 \\
$\mathrm{O}_{3}$ & 1027.91 & 0.18 & 0.154 \\
\hline
\end{tabular}

values suggested that $\mathrm{PM}_{2.5}, \mathrm{NO}_{2}$, and $\mathrm{O}_{3}$ could explain only $24.6 \%, 0.03 \%$ and $15.4 \%$ of variation on COVID-19 fatality rates. This was further corroborated by $R^{2}$ values $\left(0.27\right.$ for $\mathrm{PM}_{2.5}, 0.00038$ for $\mathrm{NO}_{2}$ and 0.18 for $\mathrm{O}_{3}$ ). COVID-19 fatality rate is a complex function, influenced by a number of cofactors. A simple two-variable correlation or association alone deems insufficient to comprehend 
the COVID-19 fatality rate. There are several other relevant socio-economic and environmental factors which impact the pandemic diffusion and fatality. An inclusive inter-disciplinary and multi-dimensional investigation is required at a comprehensive level to efficiently evaluate the pandemic's causation and its consequences.

\section{ACKNOWLEDGMENTS}

The authors acknowledge The Director, CSIR-IMMT and Head of E\&S Department, CSIR-IMMT, Bhubaneswar for their expression of approval and support. BR and TD are grateful to ISRO-GBP (ATCTM \& ARFI) for the financial support.

\section{DISCLAIMER}

The authors declare that they have no conflict of interest.

\section{SUPPLEMENTARY MATERIAL}

Supplementary data associated with this article can be found in the online version at https://doi.org/10.4209/aaqr.2020.07.0410

\section{REFERENCES}

Benkert, K., Gabriel, E., Resch, M.M. (2008). Outlier detection in performance data of parallel applications. 2008 IEEE International Symposium on Parallel and Distributed Processing, pp. 1-8.

Bontempi, E., Sergio, V., Flaminio, S. (2020). Understanding COVID-19 diffusion requires an interdisciplinary, multi-dimensional approach. Environ. Res. 188, 109814. https://doi.org/10.1 016/j.envres.2020.109814

Chakrabarti, S.S., Kaur, U., Banerjee, A., Ganguly, U., Banerjee, T., Saha, S., Parashar, G., Prasad, S., Chakrabarti, Suddhachitta, Mittal, A., Agrawal, B.K., Rawal, R.K., Zhao, R.C., Gambhir, I.S., Khanna, R., Shetty, A.K., Jin, K., Chakrabarti, S. (2020). COVID-19 in India: Are Biological and Environmental Factors Helping to Stem the Incidence and Severity? Aging Dis. 11, 480-488. https://doi.org/10.14336/ad.2020.0402

Chen, N., Zhou, M., Dong, X., Qu, J., Gong, F., Han, Y., Qiu, Y., Wang, J., Liu, Y., Wei, Y., Xia, J., Yu, T., Zhang, X., Zhang, L. (2020). Epidemiological and clinical characteristics of 99 cases of 2019 novel coronavirus pneumonia in Wuhan, China: A descriptive study. Lancet. 395, 507-513. https://doi.org/10.1016/S0140-6736(20)30211-7

Conticini, E., Frediani, B., Caro, D. (2020). Can atmospheric pollution be considered a co-factor in extremely high level of SARS-CoV-2 lethality in Northern Italy? Environ. Pollut. 261, 114465. https://doi.org/10.1016/j.envpol.2020.114465

Frontera, A., Cianfanelli, L., Vlachos, K., Landoni, G., Cremona, G. (2020). Severe air pollution links to higher mortality in COVID-19 patients: The "double-hit" hypothesis. J. Infect. 81, 255-259. https://doi.org/10.1016/j.jinf.2020.05.031

Hendryx, M., Luo, J. (2020). COVID-19 prevalence and fatality rates in association with air pollution emission concentrations and emission sources. Environ. Pollut. 265, 115126. https://doi.org/10.1016/j.envpol.2020.115126

Li, X., Ma, X. (2020). Acute respiratory failure in COVID-19: Is it "typical” ARDS? Crit. Care 24, 198. https://doi.org/10.1186/s13054-020-02911-9

Liang, D., Shi, L., Zhao, J., Liu, P., Sarnat, J.A., Gao, S., Schwartz, J., Liu, Y., Ebelt, S.T., Scovronick, N., Chang, H.H. (2020). Urban air pollution may enhance COVID-19 Case-fatality and mortality rates in the United States. Innovation 1, 100047. https://doi.org/10.1016/j.xinn.2020.100047

Manning, M., Martin, R., Hasenkopf, C., Flasher, J., Li, C. (2018). Diurnal patterns in global fine particulate matter concentration. Environ. Sci. Technol. Lett. 5, 687-691. https://doi.org/10.10 21/acs.estlett.8b00573 
Ogen, $\mathrm{Y} .(2020)$. Assessing nitrogen dioxide $\left(\mathrm{NO}_{2}\right)$ levels as a contributing factor to coronavirus (COVID-19) fatality. Sci. Total Environ. 726, 138605. https://doi.org/10.1016/j.scitotenv.2020. 138605

Pansini, R., Fornacca, D. (2020). COVID-19 higher morbidity and mortality in Chinese regions with lower air quality. medRxiv 2020.05.28.20115832. https://doi.org/10.1101/2020.05.28.20115832

Pope, C.A. (2000). Review: Epidemiological basis for particulate air pollution health standards. Aerosol Sci. Technol. 32, 4-14. https://doi.org/10.1080/027868200303885

Russell, A.G., Brunekreef, B. (2009). A focus on particulate matter and health. Environ. Sci. Technol. 43, 4620-4625. https://doi.org/10.1021/es9005459

Salkind, N. (2010). Encyclopedia of research design. SAGE Research Methods.

Sicard, P., Khaniabadi, Y.O., Perez, S., Gualtieri, M., De Marco, A. (2019). Effect of $\mathrm{O}_{3}, \mathrm{PM}_{10}$ and $\mathrm{PM}_{2.5}$ on cardiovascular and respiratory diseases in cities of France, Iran and Italy. Environ. Sci. Pollut. Res. 26, 32645-32665. https://doi.org/10.1007/s11356-019-06445-8

Stephanie, G. (2016), https://www.statisticshowto.com/omega-squared (accessed 3 July, 2020). Wu, X., Nethery, R.C., Benjamin, M., Ma, S., Braun, D., Dominici, F., Gamble, C.J. (2020). Exposure to air pollution and COVID-19 mortality in the United States. Sci. Adv. 26, eabd4049. https://doi.org/10.1126/sciadv.abd4049

Yao, Y., Pan, J., Wang, Weidong, Liu, Z., Kan, H., Qiu, Y., Meng, X., Wang, W. (2020). Association of particulate matter pollution and case fatality rate of COVID-19 in 49 Chinese cities. Sci. Total Environ. 741, 140396. https://doi.org/10.1016/j.scitotenv.2020.140396 